thereby enabling a future business historian to trace the firm's history down to its termination in 1935 . The collection constitutes a valuable addition to the material on Business History now assembled at the Harvard Business School.

\title{
Wanted: Material on the History of Marketing
}

SEVERAL officers of the Society recently interviewed members of the Faculty of the Harvard Business School in order to ascertain to what extent historical material would be of special value in the course work of the School. This inquiry had a two-fold purpose: (I) to discover wherein those working in the field of Business History might be of greatest immediate service to current teaching and research in business subjects; and (2) to obtain guidance in the collection and preservation of documentary material pertaining to Business History. It was, in short, an attempt to survey some of the current needs of Business History.

It is evident from the results of the inquiry that there is an immediate need to collect and study historical material on many particular phases of business. The one topic on which information is especially wanted is a history of marketing. Despite the importance of the distribution of commodities in modern society, there is a surprising lack of factual data regarding the major historical developments in the field, and there is reason to believe that an adequate history of marketing in America would not only be of general interest but would also be of direct value in solving some of the distribution problems which confront business today.

The Business Historical Society desires to be of service in the preparation of a history of marketing, and members of the Society are urged to assist in the collection of material. We want to know, for example, when and where wholesalers split off from the importers in eastern and southern ports, leaving the latter to specialize in foreign trade; when and why retailing and wholesaling became generally divorced; how wholesalers established connections with new markets as the nation expanded to the west; and what the circumstances were which led to the emergence of such specialists as brokers, selling agents, jobbers, commission dealers, warehousemen, credit houses like Dun and Bradstreet, and the ubiquitous traveling salesman. We also want 
material on the history of auction selling, produce and commodity exchanges, mail-order houses, and similar enterprises.

There has always been a constant fight for survival among the various marketing institutions-the kind of struggle which we have been witnessing in recent years between independent retailers and chain stores. At one period the wholesaler was supreme, at another some of his functions were absorbed by the manufacturer or the retail chain organization. Similarly, agents and brokers have split off from producing or distributing institutions, only to be absorbed in the process of integration which has led to the formation of our modern business giants. There has been a constant rise and fall of middlemen, a perpetual shift between specialization and re-combination of marketing functions. We want to trace the pattern and to discover the various factors which have brought about the changes.

Information is needed on every aspect of the operations of individual firms in the marketing field. On their internal operations we need data about various expense ratios, profit margins, trade and quantity discounts, methods of accounting and inventory control, purchasing, trade marks and brands, advertising, financing, and all phases of administration, including personnel management, sales organization, and the formation of business policies. Topics of a more general nature include changes in the general costs of distribution, the rate of the style cycle (for example, the duration of the fashion for short skirts or home knitting) and its repercussions on selling, the relations between department stores and bankers, the financing of retailers by wholesalers, the effect of technical development upon the storage or packaging of goods, the influence of local transportation upon department store sales, and the correlation of commodity prices and general business trends.

Adequate information on some of the topics mentioned may never be forthcoming, but much data is to be obtained from the account books, correspondence, and other records of early mercantile firms, village stores, department stores, wholesale houses, and related businesses. Nineteenth century material is likely to be of great value on many points, but we are also interested in data for the recent period, especially records revealing marketing history during and after the World War and through the depression, including the effects of the National Industrial Recovery Administration.

Some of the material we want is lying in attics, basements, or store rooms-unused and unwanted. Some of it is in the files of going concerns who will soon destroy it unless its value to the historian is brought 
to their attention. It is exceedingly important to rescue such records before they are thrown into the fire. Any one who knows of any material which bears even remotely on the history of marketing is urged to communicate at once with the Executive Secretary of the Society.

\section{Collection of Photographs of Contemporary Business Leaders}

As indicated in the May and June Bulletins, the Society has interested itself in securing the photographs of our contemporary business leaders, to supplement a similar collection of the photographs of pioneers in American industry, which has been assembled only after considerable difficulty. The following additional photographs are gratefully acknowledged:

Mr. George F. Baker, Banker, New York City.

Mr. E. T. Bedford, President, Corn Products Refining Company, New York City.

Mr. S. T. Bledsoe, President, Atchison, Topeka \& Santa Fé Railway Company, Chicago.

Mr. Horace Bowker, Chairman, American Agricultural Chemical Company, New York City.

Mr. John Nicholas Brown, Financier, Providence, Rhode Island.

Mr. Charles S. Calwell, late President, Corn Exchange National Bank, Philadelphia.

Mr. E. J. Cornish, President, National Lead Company, New York City.

Mr. George B. Cortelyou, President, Consolidated Gas Company, New York City.

Mr. Jere A. Downs, Partner, Hayden, Stone \& Company, Boston.

Hon. W. Cameron Forbes, former American Ambassador to Japan, Boston.

Mr. John W. Higgins, President, Worcester Pressed Steel Company, and The John Woodman Higgins Armory, Worcester, Massachusetts.

Mr. A. F. Hockenbeamer, President, Pacific Gas and Electric Company, San Francisco.

Mr. Fred A. Howland, President, National Life Insurance Company, Montpelier, Vermont.

Mr. Cyrus H. McCormick, Inventor of the reaping machine (1809-1 884).

Mr. F. A. Merrick, President, Westinghouse Electric \& Manufacturing Co., East

Pittsburgh, Pa. 